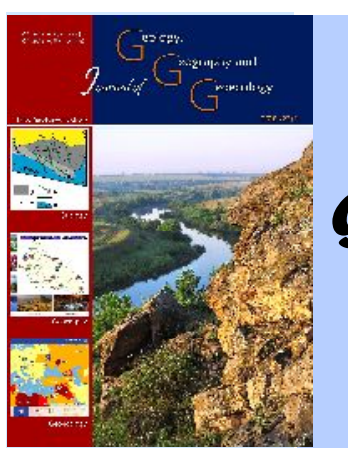

Chyr N.V.

\section{Journal of Geology.}

Geography and Geoecology

\author{
Journal home page: geology-dnu-dp.ua
}

Journ.Geol.Geograph.

Geoecology,

27(1), 51-59

doi: $10.15421 / 111830$

Journ.Geol.Geograph.Geoecology,27(1), 51-59

\title{
Tendencies in Photo Tourism Development in Ukraine (on the example of Transcarpathian region)
}

\author{
Chyr N.V.
}

State higher educational establishment "Uzhgorod National University", city of Uzhgorod, Ukraine e-mail: Nadezda_chyr@i.ua

Received 13.04.2018;

Received in revised form 20.04.2018;

Accepted 08.06.2018

Abstract. The purpose of this article is to investigate the main vectors of photo tourism development in Ukraine as an innovative trend in active tourism. On the basis of systematization of the definitions available, the author presents her own vision of the concept "photo tourism", as well as its main functions. The author gives a brief outline of the geography of the most popular photo tours in the world and emphasizes prospects for development of photo tourism within Ukraine on the basis of the touristic recreational potential available. Among the most popular destinations of photo tourism in the world for street photography and genre photography we can highlight Europe. Paris, Rome, Amsterdam, Madrid, Prague and Lisbon are considered to be truly picturesque photo locations. In terms of scenery tours, the top ranking directions are exotic ones, such as South-East Asia, Central Asia, the Middle East, India, Tibet, China, Nepal, Ethiopia, Bhutan and Malaysia. The whole territory of Ukraine is appealing in terms of photo tour development, though the Ukrainian Carpathians and the Crimea possess the best qualities for scenery, panoramic and genre photography. At present photo tours are being actively carried out only in the Western regions of the country. The most interesting natural locations have been described, which might become the basis for photo tours within the boundaries of Ukraine in the future. The objects to be captured by the camera lens are mostly historical and cultural heritage - castles, fortresses, palace complexes. The Chornobyl Exclusion Zone has become a particularly interesting photo location. A range of schematic maps depicting tourist photo locations in the West of Ukraine has been created. The second vector of the development of photo tourism in Ukraine is the landscapes of the Carpathian Mountains. The following photo tours are successfully implemented and the most popular among tourists: "The Marmaros Mountains: photo trip along the Ukraine - Romania border"; "Verkhovyna Watershed Ridge"; "Borzhava Mountain Valley"; "Pre-Watershed Gorgany"; "Svydovets Massif"; "Marmaros Massif". The article analyzes the photo tour proposals nowadays available for Ukrainian tourists, their value and territorial organization. The findings of the research suggest that photo tourism is predominantly directed outside the boundaries of Ukraine whereas the development of internal photo tourism is significantly slower. The benefit of the study is that the author has developed a new tourist product in the market of tourist services of Ukraine - the programme of the photo tour "Gastronomic Transcarpathia". Food photography of Transcarpathian cuisine is considered to be a promising and innovational element in the development of the tourist industry in the region. This article mentions limiting factors hindering development of photo tourism in Ukraine and in Transcarpathian region in particular.

Key words: photo tourism, photo tour, photo location, food photography, gastronomic photo tour, Transcarpathian region.

\section{енденції розвитку фототуризму в кр їні}

ир . .

«жгородський н ціон льний університет»,м.жгород, кр їн , е-таil: Nadezda_chyr@i.ua

нот ція. озгляд ється пит ння суч сних тенденцій розвитку фототуризму як нового сегмент н ринку туристичних послуг кр їни. еред популярних н прямків фототуризму в світі для стрит-фотогр фії т ж нрових зйомок виділяється вроп . олоритними фотолок ціями вв ж ються риж, им, мстерд м, дрид, р г, іс бон. пейз жних тур х першість н лежить екзотичним н прямк м: івденно- хідн зія, ередня зія, лизький хід. кр їні н йкр щими вл стивостями для розвитку фототуризму х р ктеризуються кр їнські рп ти т рим. ьогодні фототури ктивно ре лізуються лише в 3 хідних регіон х кр їни. об'єктив фоток мер перев жно потр пляє історико-культурн сп дщин - $з$ мки, фортеці, п л цові комплекси. собливо цік вою фотолок цією ст л орнобильськ зон відчуження. ругий вектор розвитку фототуризму в кр їні ст новлять, л ндш фти рп тських гір. д ло ре лізуються фототури: « рм роські гори: фотом ндрівк укр їнсько-румунським кордоном»; « ерховинський вододільний хребет»; « олонин орж в »; « ривододільні орг ни»; « видовецький м сив»; « рм роський м сив». иділено н йбільш цік ві природні лок ції, які в м йбутньому можуть ст ти 
льтерн тивною основою фототурів у меж х $\quad$ кр їни. творено низку к ртосхем туристичних фотолок цій обл стей хідної

кр їни. ст новлено, що н йбільш н сичені цік ві туристичні тр кції-це к рп тськ і ернопільськ обл сті. ро н лізов но н явні пропозиції фототурів н укр їнському ринку, їх в ртість т територі льну орг ніз цію. езульт ти дослідження ілюструють перев жну спрямов ність фототуризму з межі кр їни, в той ч с, коли внутрішній фототуризм розвив ється зн чно сл бше. озроблено новий туристичний продукт н ринку туристичних послуг кр їни прогр му фототуру « строномічне к рп ття», що репрезентуе інтерн ціон льний т с мобутній колорит прикордоння. уд-фотогр фія 3 к рп тської кухні може ст ти іннов ційним елементом у розвитку індустрії туризму кр ю і в перспективі з лучити не тільки фотолюбителів, й поціновув чів різних н прямів г строномічного туризму, етнічного туризму тощо. онкурентну перев гу розвитку фототуризму в меж х к рп тської обл сті ст новить поширення сільських л ндш фтів. йомк сільських мотивів для іноземців ст л б новим поштовхом для пізн ння кр їни і водноч с льтерн тивою «урб нізов ної вропи». еред перспективних векторів розвитку фототуризму виокремлено: п м'ятки рхітектури т містобудув ння (середньовічні 3 мки к рп ття, міськ рхітектур жгород, ук чев , ерегов , уст ); культурну скл дову (фестив лі, свят , звич ї, обряди, тр диційний одяг); унік льні з повідні місця ( мерековий к мінь, б вський к мінь, околині скелі, печери гольського м сиву т урочищ ерлений к мінь, олонин ун , нт ловецьк полян ); ш фр нові поля у дендрологічному п рку « ерезинк » н ук чівщині т в с. олоч в іжгірського р йону; л в ндові поля в жгородському р йоні, олин н рцисів в урочищі иреші устського $\mathrm{p}$ йону. креслено основні лімітув льні чинники розвитку фототуризму н терен $\mathrm{x}$ кр їни в цілому т в к рп тській обл сті зокрем .

лючові слов : фототуризм, фототур, фотолок ція, фуд-фотогр фія, г строномічний фототур, $к$ рп тськ обл сть.

Introduction: Recently, photo tourism has emerged as one of the most popular forms of active leisure and is currently characterized by particularly dynamic development. This special and innovative trend of tourism attracts like-minded people willing to share their experience and ideas and to tell the world about the most beautiful corners of our planet through their photos.

The investigation of the modern aspects of photo tourism development in Ukraine is a matter of extremely topical interest, as on the one hand, this trend of touristic activity is new and scantily explored, but on the other hand, the prospects for its further development are excellent. Foreign authors N. Snavely, S. Seitz, R. Szeliskib (Snavely, Seitz, Szeliski, 2006)], P.D. Osborne (Osborne, 2000), J. Larsen (Larsen, 2006) mostly highlight the specificity of organizing photo tours, the role and significance of photography in choosing the itinerary of a trip. This topic has not been well-investigated in Ukraine. Certain general aspects as well as peculiarities of photo tourism development can be found in the works of the domestic authors: O. Beidyk (Beidyk, 2013), T. Krasnov, S. Kolodiy, I. Melika (Melika, 2012), S. Lyshayev, A. Bilous (Bilous, 2013), N. Zalevska (Zalevska, 2015). For example, O. Beidyk in the Tutorial "Unique Ukraine: geography and tourism resources" investigated attractive natural, historical and cultural objects with prospects for photo tourism development. Bilous A. and Lyshayev S. consider photo tourism as innovative trend of tourism activity and characterize the most popular photo tourism routes. Zalevska N. explored the implementation of photo tourism in the hotel industry. She also has developed the photo tour of prominent objects of Kyiv and Kyiv region. Melika I. and Kolodiy S. investigated technical aspects of organizing photo tours. However, such issues as analysis of the most promising photo locations within the territory of Ukraine and development of the viable tourist routes have not been thoroughly investigated or completed yet.

The purpose of this article is to characterize the major vectors of developing photo tourism as a new segment in the market of tourist services of Ukraine on the whole and on the territory of Transcarpathian region in particular; to develop thematic photo tour on the territory of Transcarpathian region. Materials and methods of investigation. In the process of investigation, the following methodological tools were implemented: methods of analysis and synthesis, observation, comparison, description, historical method, cartographic method, statistical analysis; the programme Foto Fusion5 was used for creation of a photo location map.

Results and their analysis. There exists a variety of definitions of the concept "photo tourism". On the basis of analysis of the interpretations available, we offer our own vision of this notion. Photo tourism is a form of active tourism which is a symbiosis of tourism and photo art, and is carried out predominantly by amateur photographers, for whom tourist attractions are as important as their characteristics (aesthetic value, contrast range, picturesqueness etc.). The main characteristic feature of photo tourism is the fact that it not only enables a person to discover new destinations and visit monuments of natural, historical and cultural heritage, but also to increase the level of their photographic competence and enrich their portfolio with new photos (Ukrainska asotsiatsiia aktyvnoho ta ekolohichnoho turyzmu, Ukrainian Association of Active and Ecological Tourism ,2018).

We can single out several functions of photo tourism: informative, educative, entertaining, health-improving, communicative and creative.

In the Western Europe, the development of photo tourism soared around thirty years ago. By the way, the nation that is the keenest on photography is 
the French. The geography of photo tours is extremely wide. Among the most popular directions we can highlight Europe - for street photography and genre photography. Paris, Rome, Amsterdam, Madrid, Prague and Lisbon are considered to be truly picturesque photo locations. In terms of scenery tours, the top ranking directions are exotic ones, such as South-East Asia, Central Asia, the Middle East, India, Tibet, China, Nepal, Ethiopia, Bhutan and Malaysia. There are also numerous destinations in Southern America, countries of the Caribbean Basin, Australia and Iceland (Zalevska, 2015). Photo tourism is quite well-developed in the USA as well. The most popular centers for its development on the North American continent are New York, London, San Francisco, Chicago, Paris, Los Angeles, Washington, and Seattle.

Nowadays Ukraine could find its niche in this segment of the tourist market and position itself as a country with prospects for photo tourism development. The whole territory of Ukraine is appealing in terms of photo tour development, though the Ukrainian Carpathians and the Crimea possess the best qualities for scenery, panoramic and genre photography (Bilous, 2013).

At present, photo tours are being actively carried out only in the Western regions of the country. The objects to be captured by the camera lens are mostly historical and cultural heritage - castles, fortresses, palace complexes. The Chornobyl Exclusion Zone has also become a particularly interesting photo location.

Ukraine can boast numerous attractive and unique natural objects which could be of great interest to amateur photographers. The most promising of them are:

- Oleshkivsky Pisky - one of the few deserts of Europe. Nowadays it is considered to be the largest sandy area of Europe, which consists of seven so called arenas. All of them are hilly, with fluctuation of the peaks up to $20 \mathrm{~m}$. Since 2010 this territory has been a National Natural Park.

- The Tunnel of Love - the most romantic place in Rivne region, which is considered to be a botanical phenomenon. It is located along the railway between the towns Klevan and Orzhiv.

- Shatsky Lakes - a group of over 30 lakes in the north-western part of Volyn region, in the interfluve of the Pripyat and the Western Buh. They are an integral part of the Shatsky National Natural Park. The biggest of the lakes - Svityaz - is the deepest lake of Ukraine.

- Lake Synevyr, or the so called "Sea Eye", is considered to be the most valuable natural treasure of the National Natural Park "Synevyr", and one of the most well-known attractions of the Ukrainian Carpathians. The landscape around the lake, which is utterly spectacular and majestic, has always attracted the video cameras of famous film directors. On its banks, several films have been shot, such as "Synevyr" (the first Ukrainian horror film), "Brothers. The Final Confession", the Ukrainian-French co-production thriller "The Last Step" with Jean Reno as the leading character.

- The Dnister Canyon - the largest in Ukraine and one of the largest canyons in Europe, which was formed as a result of washing out the rocks of the Podol Highland by the river Dnister. It is a valley whose steep banks reach from $100 \mathrm{~m}$ to $250 \mathrm{~m}$ above the water surface. There are approximately 100 natural wonders and inanimate nature landmarks of global importance, as well as unique samples of cleavage, which are well-preserved.

- Granite-steppe Lands of Buh - one of the most ancient dry lands in Eurasia are located in the north-west of Mykolayiv region. The place is characterized by a unique ecosystem with a variety of relicts and endemics of Mediterranean and Alpine origin. Eighty-six representatives of flora and fauna that are included in the Red Book of Ukraine and the European Red List have been discovered here (Beidyk, 2013).

- Optimistic Cave - the world's longest gypsum labyrinth, is located in Borshchiv district of Ternopil region, to the south-west of the village of Korolivka, in the natural boundary "Korolivka". The most valuable treasure of the cave is secondary mineral formations, which have been growing here in subterranean cavities for dozens of thousands years.

- The Uritsky Rocks - a natural wonder and archeological landmark of national importance, which does not have any analogues in Europe, is located near the village of Urych in Lviv region. The Urytsky Rocks are a part of the historical landscape complex "Tustan". The landmark impresses visitors with its rock paintings depicting solar images and the symbol of the Sun, the purpose of which has not been discovered by scientists yet.

- The reserve "The Stone Graves" is a mountainous country in miniature located in the town of Nazarivka in Donetsk region. The unique granites of the reserve, aged up to two billion years, do not have any analogues in the world (Beidyk, 2013).

In our view, the following popular photo locations in Ukraine are also worth mentioning: the city of Berdyansk in Azov region; Yarenche - the Pearl of the Carpathians; the Sophia Park in Uman; Castle Palanok in Mukachevo; Vylkove - the Ukrainian Venice; Lviv - the centre of Ukrainian culture; Kamyanets-Podilsky - the city of seven cultures; the Narcissus Valley; the dendropark in Kropyvnytsky; Uzhgorod in the period when oriental cherry trees bloom there; Askania-Nova, a biosphere reserve, 
with its blooming flora; the urban-type settlement Olyka - "Versailles" in Volyn region.

We have created a range of schematic maps depicting photo tourism locations in the West of Ukraine. Having thoroughly analyzed all the regions within this territory, we have come to a conclusion that the most vivid and interesting of them are Transcarpathian and Ternopil regions (Figures 1-2). The analysis takes into account both quantitative indicators (the degree of saturation of historical, cultural and interesting natural objects) and qualitative parameters (their attractiveness and uniqueness).
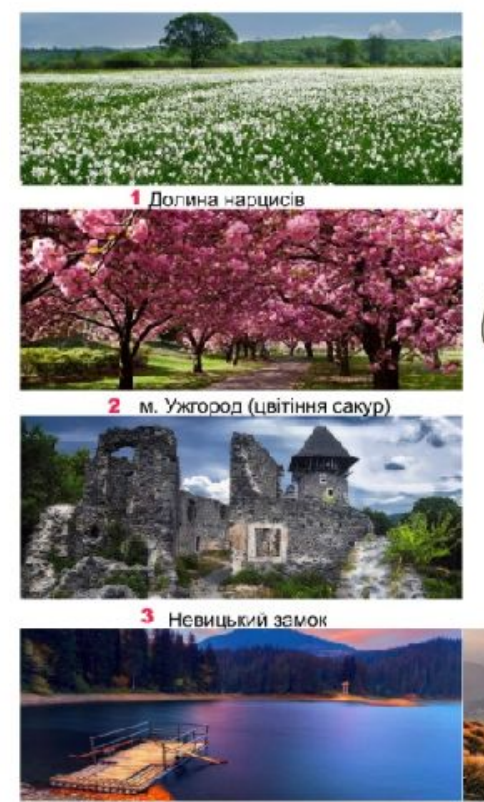

4 оз.Синевир

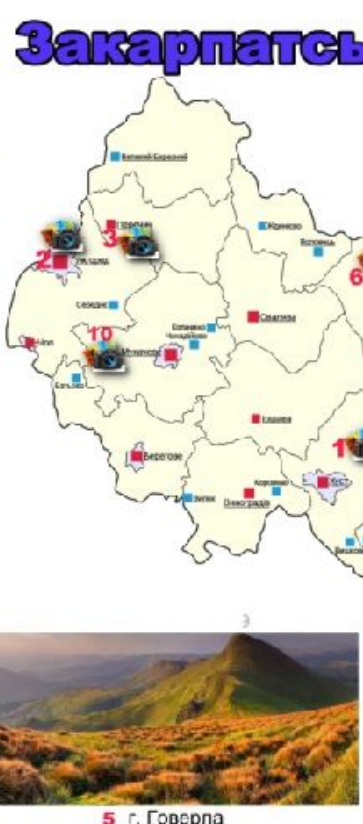

5 г. Говерna
The photo tours are usually organized by tourist companies and photography schools (Ukrainska asotsiatsiia aktyvnoho ta ekolohichnoho turyzmu, Ukrainian Association of Active and Ecological Tourism ,2018). In Ukraine this tourist product is offered by the tourist company "Phototours", of Kyiv Photography School, as well as independent professional photographers. Tours organized by groups of enthusiasts guided by experienced photo tourists are gaining more and more popularity.

Fig. 1. Photo tourism locations in Transcarpathian region

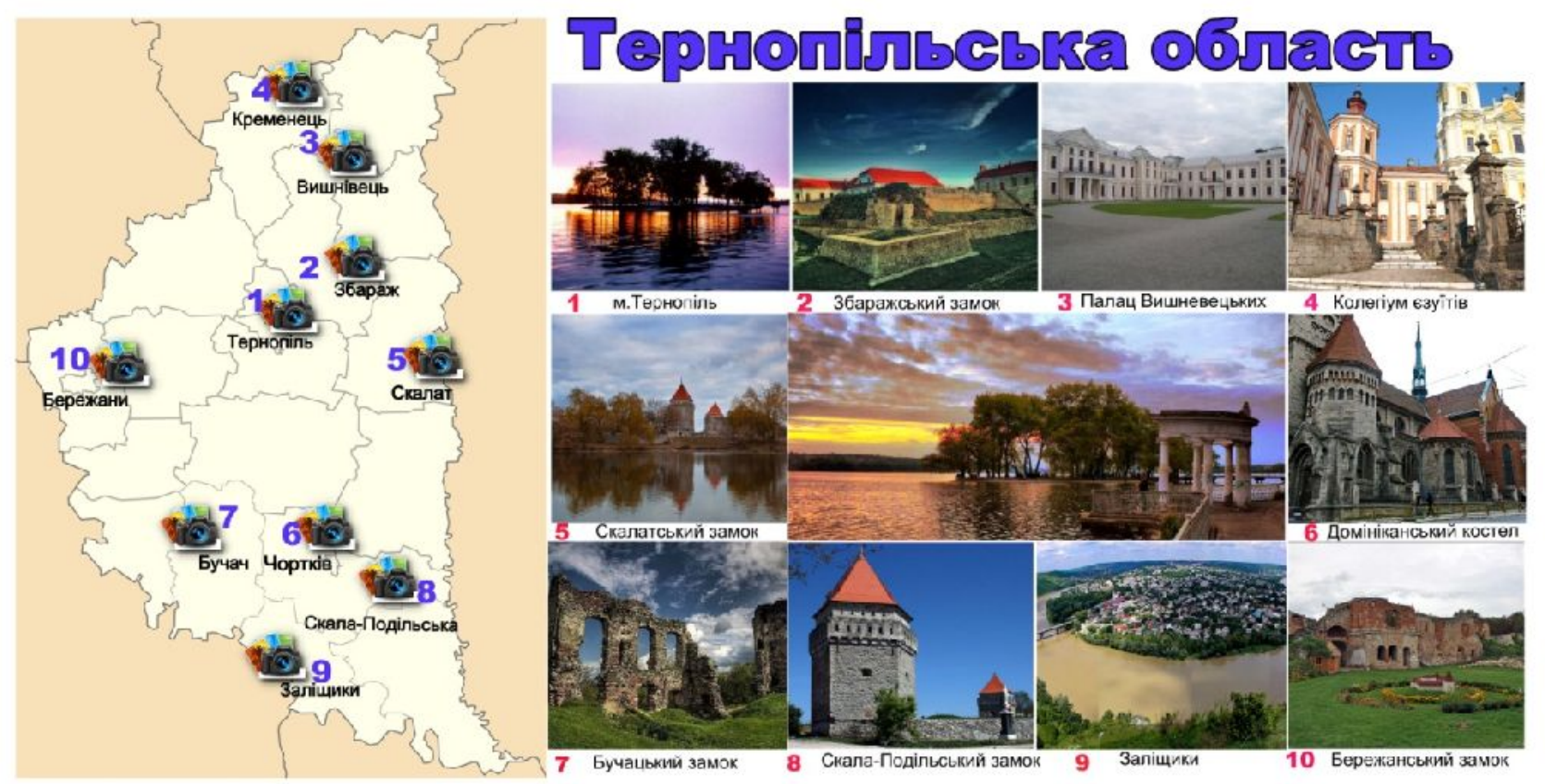

Fig. 2. Photo tourism locations in Ternopil region 
Moreover, we have made an attempt to systemize the proposals of the photo tours currently available in Ukraine. The list of the world photo tours organized by the company "Phototours" is presented in Table 1 below.

Kyiv Photography School is the first school in Ukraine where you are taught the mastery of photography. It organizes various photo tours and photo expeditions to the most picturesque places of Ukraine and around the whole world. The following photo tours are the most popular among tourists: "Along the Golden Roads of Georgia", "Christmas Prague and Munich", "The Tulips of Amsterdam", "Indian Holi", "Carpathian Weekend", "Legends of Transcarpathia", "Autumn in Transcarpathia" (Ukrainska asotsiatsiia aktyvnoho ta ekolohichnoho turyzmu,
Ukrainian Association of Active and Ecological Tourism ,2018).

The findings of the research suggest that photo tourism is predominantly directed outside the boundaries of Ukraine whereas the development of internal photo tourism has been significantly slower. Nowadays just a few tourist agencies provide services of photo tours around Ukraine, most of which are aimed at photography of mountainous sceneries of the Ukrainian Carpathians. Such trips are mainly organized by professional photographers that crave to improve their mastery as well as share their experience with the trainees, but due to the unavailability of organized photo tourism, more and more often they are forced to give their preference to amateur tourism creating their own projects.

Table 1. The list of photo tours offered by the tourist company "Phototours" (Turystychna kompaniia «Phototours», 2018)

\begin{tabular}{|c|c|c|c|c|}
\hline Name of photo tour & Destination country & Period & Cost, \$ USA & Format \\
\hline \multicolumn{5}{|c|}{2015} \\
\hline Demerdgy Gold & Crimea & April & 500 & photo expedition \\
\hline Legends of the Winter Caucasus & Russia & April - May & 700 & photo tour \\
\hline Canyons of the Bugsky Guard & Ukraine & June & 200 & photo tour \\
\hline $\begin{array}{l}\text { Winter Melodies of the Carpathian } \\
\text { Mountains }\end{array}$ & Ukraine & June & 300 & photo hiking tour \\
\hline Colour of the Dolomites & Italy & July & 1300 & photo tour \\
\hline Italian Photo Holidays & Italy & October & 1900 & photo tour \\
\hline Uzbekistan - Eastern Flavour & Uzbekistan & November & 1500 & photo expedition \\
\hline Adygeya Giants & Russia & May & 500 & photo hiking tour \\
\hline Two Pearls of Gorgany & Ukraine & April & 159 & photo hiking tour \\
\hline \multicolumn{5}{|l|}{ 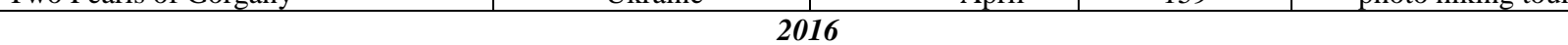 } \\
\hline Magic of the Alpine Lakes & Italy & April & 1300 & photo tour \\
\hline Winter Bavaria & Germany & April - May & 1100 & photo expedition \\
\hline Italian Photo Polidays & Italy & December & 1000 & photo tour \\
\hline Adygeya Photo Holidays & Russia & June & 500 & photo hiking tour \\
\hline Two Pearls of Gorgany & Ukraine & July & 150 & photo hiking tour \\
\hline Bugsky Guard & Ukraine & September & 200 & photo tour \\
\hline \multicolumn{5}{|c|}{2017} \\
\hline Northern Lights & Sweden, Norway & April & 1500 & photo expedition \\
\hline Italian Spring & Italy & April - May & 1200 & photo tour \\
\hline Magic of the Alpine Lakes & Italy & June & 1100 & photo tour \\
\hline Rhododendrons of the Great Tkhach & Russia & June & 350 & photo hiking tour \\
\hline Soul of the Carpathian Mountains & Ukraine & July & 200 & photo hiking tour \\
\hline Gold of the Dolomites & Italy & October & 1100 & photo tour \\
\hline Everest Base Camp Phototrek & Nepal & November & 1600 & photo expedition \\
\hline \multicolumn{5}{|c|}{2018} \\
\hline Northern Lights & Sweden, Norway & April & 1400 & photo tour \\
\hline Italian Spring & Italy & May & 1000 & photo tour \\
\hline Rhododendron of the Great Tkhach & Russia & June & 350 & photo hiking tour \\
\hline Two Pearls of Gorgany & Ukraine & July & 150 & photo hiking tour \\
\hline Around Iceland & Iceland & August & 1300 & photo tour \\
\hline Heart of Iceland & Iceland & September & 1500 & photo tour \\
\hline
\end{tabular}

A vivid example of such a project is a photo project by Serhiy Topolnytsky "Ukrainian Photography", which was initiated with the intention to revive the Ukrainian photo industry. The following photo travelers can be mentioned as the famous guides engaged in organizing photo tours in the Carpathian Mountains: Denys Kryvyi, Ihor Melika, Yuriy Shevchenko.
Photo tours in the Ukrainian Carpathians last on average 3-4 days. The minimal price is 1500 $\mathrm{UAH}$ and can reach up to $4000 \mathrm{UAH}$. The tourist usually pays extra only for the transfer to the transit city. Further, the group is transported by the organizers to the spot in the mountains where the route begins. The number of people in the group can vary 
from 4 to 15-20 individuals (Turystychna kompaniia «Phototours», 2018).

Below we give a brief overview of some of the most popular routes of photo tours within the boundaries of the Ukrainian Carpathians, which have been organized by Denys Kryvyi for the last three years (Kryvyi, 2015):

1. Route "From Pip to Pip". The tourist is offered to cover the Marmaros and Chornohirsky massifs, to see the "Hutsul Alps" and the highest installation ever constructed in Ukraine - Polish stone observatory located on the top of the mountain PipIvan Chornohirsky.

The progression of the route: village Dilove mountain pasture valley Lysycha mountain PipIvan of the Marmaros mountain pasture valley Lechen (natural boundary Maslokrut) natural boundary Mezhypotoky mountain Mika-Mare mountain Shchaul mountain Yurchesku-Mik (Iurcescu) mountain Stih mountain Shchavnyk mountain Vykhid mountain Pip-Ivan Chornohorsky mountain Vukhaty Kamin mountain pasture valley Smotrych village Dzembronya.

Duration: 6-7 days.

Important: special permission is needed to be obtained in advance enabling the tourist group to cross the Marmaros Mountains, as this is a border zone.

2. Water and highland route "The Lakes of Chornohora". The tourist has the chance to cross the highest mountain range in Ukraine - Chornohora, to take photos of the high-altitude glacial lakes Maricheika, Brebeneskul and Nesamovyte, as well as the observatory on the top of the mountain PipIvan, which was constructed in the late 1930s .

The progression of the route: village Zelene

lake Maricheika mountain Pip-Ivan Chornohirsky mountain Dzembronya mountain Brebeneskul lake Brebeneskul mountain Rebra lake Nesamovyte traverse to the tourist camping site " $\mathrm{Za}$ roslyak".

Duration: 3-5 days.

3. Route "Mountain pasture valley Khom$y a k$ ". The Khomyaky is the simplest of the photo routes organized to last several days. It is a great location for taking photos of the Gorgany Massif, within which there are the mountains Khomyak and Synyak - rocky mountains covered with lichen, with the slopes thickly overgrown with fir and beech woods. In summer in the mountain valley you can take photos of Hutsul highlanders' routine life, in particular the process of cheese making.

The progression of the route: road to the village of Palyanytsya mountain pasture valley Khomyak mountain Khomyak mountain pasture valley Khomyak mountain Synyak mountain pasture valley Khomyak

Zhenetsky Waterfall (Huk) village Tatariv.

Duration: 2 - 4 days.

4. Photo tour "Svydovets Lakes". Apart from the lakes in the Svidovets mountain range and the mountain pasture valleys there are numerous small rivers. In sunny weather you can catch on camera the subtle sparkling reflection of the sun on the water gleaming on the bright-green slope (for this shot it is better to use a telephoto lens).

The progression of the route: village Yasinya tourist camp "Drahobrat" mountain Stih mountain ridge Apshynets lake Dogyaska mountain Dogyaska mountain Troyaska lake Apshynets mountain ridge Apshynets lake Vorozheska village Chorna Tysa.

Duration: 3 - 5 days.

The territory of Transcarpathian region is highly promising for further development of photo tourism in Ukraine. The year 2015 can be considered the starting point of its development in our area. It was in 2015 when the photo studio "Time Studia" organized a photo tour in Transcarpathia named "Mountain Rules", the programme of which included doing a personal photo project on a certain topic as well as completing various creative assignments every day. The major photo locations of the tour were the following: Borzhavska mountain pasture valley, Shypit waterfall, Lake Synevyr, Ozerna Mountain, Tereble-Ritska hydroelectric power station, the Narcissus Valley, Seliska Cheese Diary, authentic picturesque village Svoboda.

In spring 2017 a group of activist travelers "Capre Diem" from Kyiv organized in Transcarpathia a photo tour/photo battle "To Synevyr". The route covered the following locations: Kyiv Pylypets Synevyr Nyzhne Selyshche Lviv Kyiv.

Guided photo tours organized by photo traveler Ihor Melika, a well-known photographer and journalist, member of the Photographic Art Society of Ukraine and the Association of Highland Tourism of Slovakia, member of public organization "Carpathian Paths", have advanced in popularity. Among the photo tours organized by Ihor Melika the following can be highlighted: "The Marmaros Mountains: photo trip along the Ukraine - Romania border"; "Verkhovyna Watershed Ridge"; "Borzhava Mountain Valley"; " Pre-Watershed Gorgany"; "Svydovets massif"; "Marmaros Massif".

All the routes in the sphere of photo tourism currently available are aimed at capturing the landscape and scenic variety of the Transcarpathian area, thus being suitable for implementation of the scenic trend of photo tourism. By contrast, we offer a new tourist product of a genre character, which will extend the range of photo tours and, therefore, increase the number of potential tourists. The new tourist 
product will be of particular interest to foreign tourists from the Transcarpathian border area.

With the rapid development of social networks, one genre that is gaining increasing popularity is food photography. Visitors to public catering establishments take photos of their well-served meals and share them in their blogs, publics and social networks. Food photographers do this professionally. Nowadays food photography is a trend which is advancing in popularity day by day, as a professional quality photo of a dish plays an important role in attracting new clients, in advertisement of the establishment or the chef (Savchuk, 2016).

Food photography of Transcarpathian cuisine might become an innovational element in the development of the tourist industry in the region. In the foreseeable future, the development of exactly this trend could engage not only amateur photographers, but also connoisseurs of different kinds of gastronomic tourism, ethnic tourism etc. Moreover, the photo tour programme including photography and degustation of Transcarpathian cuisine would be extremely attractive to both national and foreign tourists.

Transcarpathian cuisine has been formed over many centuries under the influence of historical factors (up to 1945 the territory had been under the government of different European states - Austria-Hungary, Czechoslovakia, Hungary). Therefore, it has an international character, which seems logical. Each of the national minorities residing on the territory of Transcarpathia, contributed their own distinctive dishes to Transcarpathian cuisine, characterized by specific cooking practices. Transcarpathian Hungarians enriched it with bograch,_goulash, perkelt, poprikash, lecho, rokot-krumply, lotsy pechenye; Rumanians - with different kinds of tokans; Slovakians - with strapachky, karbonatky, bukhty; Czechs with knedly and Segedynsky goulash; Germans with schnitzel and old well-recognized recipes of Schwab beef. Transcarpathian Jews offer their traditional dishes: chovlent, liver cooked in a European way, stuffed fish; Gypsies - hurka, pohachy, roasted udder, fried rubtsy. At the same time, Transcarpathian cuisine is rich in original authentic dishes, the recipes of which have been preserved since ancient times and are absent in the menus of other peoples.

The aspect that facilitates popularization of the photo tour developed by us is availability of numerous degustation halls in the region, where you are offered to taste unique cheeses, meat dishes, lekvar (plum jam), honey, local wines or craft beers. Along with ethnoproducts, another essential component of the photo tour, in terms of its promotion on the tourist services market, should be its ecological compatibility. Furthermore, various gastronomic festivals that are held in the region throughout the year serve as a positive impetus to facilitate the development of the gastronomic photo tour: "Red Wine", "Uzhgorod Palachinta", "Varosh Palachinta", "Fire and Meat", " Berlybas Banush", "Hutsul Brynza", Festival of Riplyanka" etc.

The development of food photography of Transcarpathian cuisine is possible only on condition that the subjects of entrepreneurial activity public catering establishments - realize the necessity to preserve national authenticity, when the menu includes the names of traditional local dishes. For instance, "bograch", "banosh", "lotsy pecheny", "holasle", "kremzlyky" but not "deruny" etc.

Below you can find the programme of the newly developed photo tour "Gastronomic Transcarpathia". Duration of the tour -3 days. The progression of the route: city of Uzhgorod city of Perechyn city of Mukachevo village Nyzhnye Selyshche village Botar city of Uzhgorod (Drawing 3). The tourist group will be given a unique opportunity to get acquainted with Transcarpathia, traditions of Transcarpathian cuisine and to combine this pleasure with their hobby - photography.

Estimated cost of the tour - 3000 UAH per person. Group size -7 persons +guide.

Day 1

9:00. Meeting the tourist group at the railway station.

9:30. Check-in at hotel "Ungvarskiy"

10:00 - 11:00. Morning coffee in confectionery "Shtefanyo". Acquaintance with the group members.

11:00 - 12:00. Lecture on the topic "Food photography" and practical part of photography "Uzhgorod delicacies" together with a professional confectioner.

12:30 - 14:30. Lunch in restaurant "Detsa u Notarya" (or restaurant "Schwabenhof" with Schwab cuisine). Degustation of traditional Transcarpathian dishes. Master class on food photography provided by professionals and lecture on traditional Transcarpathian cuisine given by the guide.

15:00 - 17:00. Excursion around Uzhgorod. Walk along the linden alley, visit to Uzhgorod Castle, museum-skansen (open air museum) of Transcarpathian architecture and household life.

17:30 - 18:30. Transfer to the city of Perechyn. Master class on food blogging by a professional photographer.

19:00 - 20:00. Dinner in tavern "Pidkova". Degustation of dishes from Hungarian, Slovakian and German cuisines.

20:30 - 21:30. Return trip to Uzhgorod. Discussion of the material photographed and demonstration of food photograph processing by a professional (hotel "Ungvarskiy"). 
21:30. Free time (walk around night Uzhgorod).

\section{Day 2.}

9:00 Breakfast.

10:00 - 12:00. Transfer to the city of Mukachevo. Food lecture with practical part in restaurant "Hrafskiy Dvir".

13:00 - 14:00. Lunch in the restaurant. Degustation of interesting fish soup (holasle) cooked on the basis of Transcarpathian fish mix (carp, pike, sturgeon). Gourmets will have an opportunity to taste craft beer and exclusive garage wine in this restaurant.

14:20 - 15:40. Transfer to the village of Nyzhnye Selyshche.
16:00 - 17:00. Visit to the well-known cheese dairy, excursion. Master class on food photography of Transcarpathian cheeses and wines. Degustation.

17:20 - 19:00. Transfer to the village of Botar. On the way visit to the wine cellar in Vinogradovo district.

19:30 - 20:00. Food photography of local meats. Communication with local gourmets.

20:00 - 21:00. Dinner. Sleep time.

Day 3

9:00. Breakfast.

10:00 Return trip to Uzhgorod.

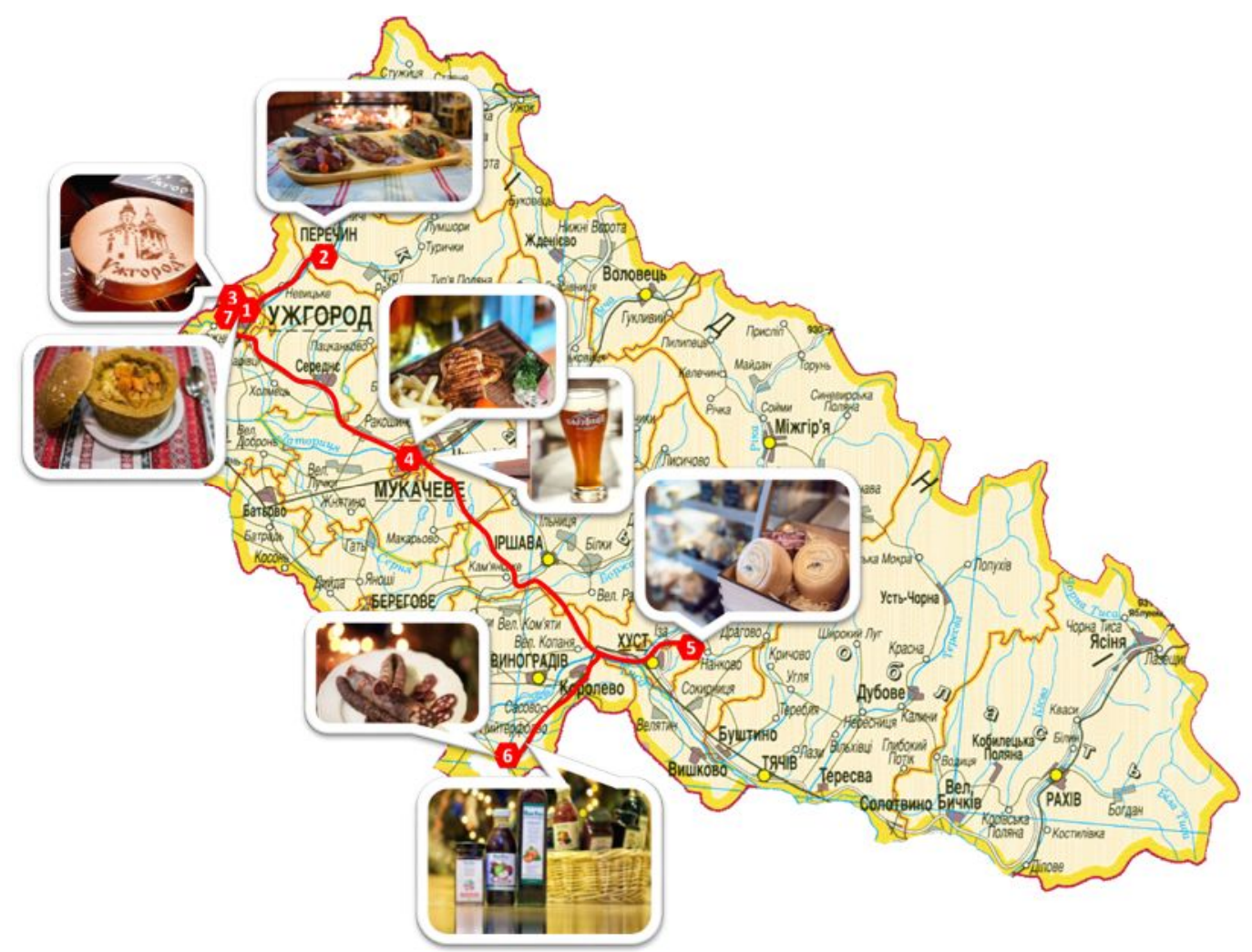

Fig. 3. Route plan of the photo tour "Gastronomic Transcarpathia"

Development of photo tours within the area will promote revival and further development of the traditional culture: national architecture, art, trades everything that contributes to the local colour of the land. Rural landscapes are the competitive advantage of Transcarpathian region. We consider that photography of rural motifs could become a new powerful spur for the foreigners to come and discover Ukraine and, simultaneously, the alternative to "urbanized Europe".

Transcarpathia can offer a huge variety of other places, which, if properly promoted, can interest both Ukrainian and foreign photographers. Among the prospective vectors of photo tourism development within the territory of Transcarpathia the following can be singled out: monuments of architecture and city planning ( medieval castles of Transcarpathia, city architecture of Uzhgorod, Mukachevo, Beregovo, Khust); cultural component (festivals, holidays, customs, traditional ceremonies, traditional clothes); unique nature reserves (Smerekovy Kamin, Obava Kamin, Sokolyni Rocks, caves of Uholka Massif and natural boundaries Cherleny Kamin, Polonyna Runa, Antalovtsy Polyana); crocus fields in the dendrology park "Berezynka" in Mukachevo district and in the village Kolochava in Mizhgirya district; lavender fields in Uzhgorod district, the Narcissus Valley in Kyresh of Khust district.

Among the main limiting factors hindering photo tourism development in Ukraine as a whole 
and in Transcarpathian region in particular, we would like to emphasize the low availability of photo tour proposals, the informational vacuum concerning tour agencies in Ukraine that offer organized photo tours within the territory of our state, the low availability of transport corresponding to European standards, the limited focus of photographers mostly on the wedding industry and individual photography, the unwillingness of professional and amateur photographers to pay money for organized tours, problematic accessibility of photo locations, especially in the Carpathian area (due to lack of personal transport), unwillingness within the photo and tourist industry to develop new trends .

Conclusions. Nowadays photo tourism is considered to be one of the most promising forms of active leisure for further development in Ukraine. It could diversify the variety of tourist services on the national market and attract more tourists, including foreigners, in the foreseeable future. At present, photo tours are being actively carried out only in the Western regions of the country. All the routes in the sphere of photo tourism currently available are aimed at capturing the landscape and scenic variety of the Transcarpathian area. As an alternative product, we have created a tourist route of a genre character photo tour "Gastronomic Transcarpathia", which could popularize the spiritual and cultural heritage of this multinational border region.

\section{Bibliographic references}

Beidyk, O.O., Novosad, N.O., 2013. Unikalna Ukraina: heohrafiia ta resursy turyzmu : navch. posib. [The unique Ukraine: geography and tourism resources]. Kyiv (In Ukrainian).

Bilous, A.V., 2013. Fototuryzm yak innovatsiinyi vyd turystychnoi diialnosti [Phototourism as an innovative kind of tourism activity]. Chasopys kartohrafii. Vyp. 9, 43-47 (In Ukrainian).

Fototuryzm, 2018. Ukrainska asotsiatsiia aktyvnoho ta ekolohichnoho turyzmu. Retrieved from http://uaeta.org/ua/tourism/25 (In Ukrainian).

Kryvyi, D., 2015. Fototury Karpatamy: marshruty dlia samostiinykh podorozhei ta porady chlenam fotohrup [Photo tours in the Carpathians: routes for self-traveling and tips for members of photo groups] Retrieved from http://firtka.if.ua/blog/print/fototuri-karpatamimarsruti-dla-samostijnih-podorozej-ta-poradi-clenam-fotogrup84400 (In Ukrainian).

Larsen, J., 2006. Geographies of Tourist Photography: Choreographies and Performances, Geographies of Communication: The Spatial Turn in Media Studies. ed., Gøteborg : NORDICOM, 243-261 Retrieved from http://rudar.ruc.dk//bitstream/1800/3848/1/geogra phies of tourist.

Melika, I., 2012. Fototur - suchasnyi produkt turystychnoho rynku [Phototour is a modern product of the tourist market]. Retrieved from http://igormelika.com.ua/moi-karpati/zbirayemosv-gori/fototur-suchasnij-produkt-turistichnogorinku (In Ukrainian).

Osborne, P.D., 2000. Travelling Light: Photography, Travel and Visual Culture. Manchester University Press, 260 p. Retrieved from https://www.amazon.co.uk/Travelling-Light-Photography-CultureCritical.

Savchuk, D., 2016. Fud-fotohrafiia. Yak fotohrafuvaty tak, shchob bulo smachno. Novyi trend fudfotohrafiia [The photo. How to take a picture so that it was delicious. The new trend food photography]. Retrieved from http://photography.in.ua/articles/advice/novyj-trend-fud-fotografiya/ (In Ukrainian).

Snavely, N., Seitz, S.M., Szeliski, R., 2006. Photo tourism: Exploring photo collections in 3D. ACM Transactions on Graphics (SIGGRAPH Proceedings). 25(3). 835-846. Retrieved from www.phototour.cs.washington.edu/Photo_Tourism.pdf.

Turystychna kompaniia «Phototours», 2018. Retrieved from https://phototours.com.ua/ (In Ukrainian).

Zalevska, N.P.,2015. Vprovadzhennia fototuryzmu v diialnist pidpryiemstv hotelnoho hospodarstva [Implementation of phototourism in the business activity of hotel industry]. Intellectual potential of the XXI century, Retrieved from http://www.sworld.com.ua/konferm2/85.pdf (In Ukrainian). 